\title{
Assessment of Allergen-Responsive Regulatory T Cells in Experimental Asthma Induced in Different Mouse Strains
}

\author{
C. T. Azevedo $\mathbb{D}^{1,2}$ A. C. Cotias $\mathbb{D}^{1},{ }^{1}$ A. C. S. Arantes $\mathbb{D}^{1},{ }^{1}$ T. P. T. Ferreira $\mathbb{D}^{1},{ }^{1}$ M. A. Martins $\mathbb{D}^{1}{ }^{1}$ \\ and P. C. Olsen $\mathbb{D}^{2}$ \\ ${ }^{1}$ Laboratório de Inflamação, Instituto Oswaldo Cruz, FIOCRUZ, Brazil \\ ${ }^{2}$ Laboratório de Estudos em Imunologia, Departamento de Análises Clínicas e Toxicológicas, Faculdade de Farmácia, \\ Universidade Federal do Rio de Janeiro (UFRJ), Av. Carlos Chagas Filho 373, Bloco A $2^{\circ}$ Andar sala 07, Cidade Universitária, \\ Ilha do Fundão, CEP. 21941-902 Rio de Janeiro, Brazil
}

Correspondence should be addressed to P. C. Olsen; priolsen@pharma.ufrj.br

Received 4 August 2021; Accepted 8 November 2021; Published 10 December 2021

Academic Editor: Calogero Caruso

Copyright (C) 2021 C. T. Azevedo et al. This is an open access article distributed under the Creative Commons Attribution License, which permits unrestricted use, distribution, and reproduction in any medium, provided the original work is properly cited.

Background. Regulatory $\mathrm{T}$ cells (Tregs) are important in regulating responses to innocuous antigens, such as allergens, by controlling the Th2 response, a mechanism that appears to be compromised in atopic asthmatic individuals. Different isogenic mouse strains also have distinct immunological responses and susceptibility to the experimental protocols used to develop lung allergic inflammation. In this work, we investigated the differences in the frequency of Treg cell subtypes among A/J, BALB/c, and C57BL/6, under normal conditions and following induction of allergic asthma with ovalbumin (OVA). Methods. Subcutaneous sensitization followed by 4 consecutive intranasal OVA challenges induced asthma characteristic changes such as airway hyperreactivity, inflammation, and production of Th2 cytokines (IL-4, IL-13, IL-5, and IL-33) in the lungs of only A/J and $\mathrm{BALB} / \mathrm{c}$ but not $\mathrm{C} 57 \mathrm{BL} / 6$ strain and evaluated by invasive whole-body plethysmography, flow cytometry, and ELISA, respectively. Results. A/J strain naturally showed a higher frequency of $\mathrm{CD} 4^{+} \mathrm{IL}-10^{+} \mathrm{T}$ cells in the lungs of naïve mice compared to the other strains, accompanied by higher frequencies of $\mathrm{CD} 4^{+} \mathrm{IL}-4^{+} \mathrm{T}$ cells. C57BL/6 mice did not develop lung inflammation and presented higher frequency of $\mathrm{CD} 4^{+} \mathrm{CD} 25^{+} \mathrm{Foxp} 3^{+}$Treg cells in the bronchoalveolar lavage fluid (BALF) after the allergen challenge. In in vitro settings, allergen-specific stimulation of mediastinal LN (mLN) cells from OVA-challenged animals induced higher frequency of $\mathrm{CD} 4^{+} \mathrm{IL}-10^{+}$Treg cells from A/J strain and $\mathrm{CD} 4^{+} \mathrm{CD} 25^{+} \mathrm{Foxp} 3^{+}$from C57BL/6. Conclusions. The observed differences in the frequencies of Treg cell subtypes associated with the susceptibility of the animals to experimental asthma suggest that $\mathrm{CD} 4^{+} \mathrm{CD} 25^{+} \mathrm{Foxp} 3^{+}$and IL-10-producing $\mathrm{CD} 4^{+}$Treg cells may play different roles in asthma control. Similar to asthmatic individuals, the lack of an efficient regulatory response and susceptibility to the development of experimental asthma in A/J mice further suggests that this strain could be preferably chosen in experimental models of allergic asthma.

\section{Introduction}

Asthma is a chronic inflammatory disease of the lungs which main symptoms are airway obstruction and reversible airway hyperresponsiveness (AHR) to nonspecific irritants. Several risk factors are involved with the development of this complex heterogeneous disease such as genetic predisposition and environmental exposure, leading to distinct phenotypes. Allergic asthma is the most common and easily treated phenotype, which is generally associated with early onset and a
Th2 immune response driven to inhaled allergens, leading to high serum IgE levels and eosinophilic lung infiltration. Regulatory $\mathrm{T}$ (Treg) cells have a key role in the maintenance of tolerance toward allergens in lung mucosa through inhibiting the activity of effector inflammatory cells that orchestrate the asthma allergic response [1-3]. These cells were initially described as a population of $\mathrm{CD} 4$ lymphocytes that expresses CD25 (IL-2 receptor $\alpha$ chain) $[4,5]$, and later, it was identified that Foxp3 (Forkhead Box 3) is a specific Treg cell marker essential to their function $[6,7]$. Different 
populations of Tregs have been described with distinct origins, mechanisms of suppression, and antigenic targets [8]. Tregs can suppress the immune response by directly inhibiting activation of Th2 and Th17 cells and activity of eosinophils and basophils through IL-10 [9-11], as well as mast cell degranulation through cell-to-cell contact [12].

The role of Tregs in asthmatic patients has been much debated; adult asthmatic patients with either stable or severe symptoms present lower amounts of Treg cells in the airways and blood, and their Tregs also present reduced suppressor activity $[13,14]$. In pediatric asthmatic patients, the percentage of Tregs in the airways was also found to be reduced [15]. Controversially, other studies have shown that the number of lung regulatory lymphocytes was increased in moderate to severe adult asthmatic patients compared with mild asthmatics and healthy subjects [16], especially following inhaled allergen provocation [17]. Discrepancies in these studies might involve different methods for analyzing Tregs and diverse cohorts. However, it is a consensus that there is a functional impairment of Tregs in asthmatics, especially concerning their ability to control Th2 responses [18]. Nevertheless, Tregs expressing Foxp3 or IL-10 correlate with decreased allergic lung inflammation and accumulate due to specific allergy immunotherapy [3, 19-21].

It is unclear also in murine models of asthma what are the roles of distinct Treg subpopulations. Divergence in studies can be a result of different antigen, mouse strain, and experimental protocols used. Therefore, we seek here to study the differences in the frequency of Foxp3 and IL10 producing Treg cells between A/J, BALB/c, and C57BL/ 6 mice that have different susceptibility to develop allergic lung inflammation, using an allergy asthma model induced with ovalbumin.

\section{Methods}

2.1. Mice. Experiments were conducted with 2 months old (18-20 g) male and female A/J, BALB/c, and C57BL/6 wildtype mice. All mice were obtained at the Oswaldo Cruz Foundation animal facility ICTB/CECAL/FIOCRUZ (Rio de Janeiro, Brazil) and were kept at the Ozório de Almeida Building/FIOCRUZ animal-housing facility with controlled room temperature $\left(22-25^{\circ} \mathrm{C}\right)$ and a $12 \mathrm{~h}$ light-dark cycle. Procedures involving the care and use of mice were examined and approved by the Animal Ethics Committee of the Oswaldo Cruz Foundation (CEUA-FIOCRUZ), Rio de Janeiro, Brazil, on August 25th of 2015 under the approval code L-030/15, for A/J, BALB/c, and C57BL/6 mice.

\subsection{Ovalbumin (OVA) Sensitization and Challenge Protocols.} The experimental asthma model was performed as described previously in detail [22], with the following modifications. Intranasal OVA challenges were given once a day from day 19 to 22 postsensitization (day 0 ).

2.3. Invasive Assessment of Lung Function. Mouse airway hyperresponsiveness was assessed $24 \mathrm{~h}$ after the final antigen challenge, as previously described [23], with the exception that the increasing concentrations of methacholine aerosolized were $0,3,9,27$, and $81 \mathrm{mg} / \mathrm{mL}$.

2.4. Histological Analysis of Lung Eosinophilic Infiltration. Mice were killed with sodium pentobarbital $(500 \mathrm{mg} / \mathrm{kg}$ i.p., (THIOPENTAX ${ }^{\circledR}$, Cristália)) after the lung function assessment. The lungs were fixed, embedded in Paraplast (Sigma), prepared for histological sections of $4 \mu \mathrm{m}$, and stained with Llewellyn's Sirius Red (Direct Red 80, C.I 35780; Sigma). Eosinophilic infiltration was evaluated around the airways, bronchial epithelium, and adventitia through an integrating eyepiece $\left(10,000 \mu \mathrm{m}^{2}\right.$ of total area) at a microscopic magnification of $1000 x$. Eosinophil counts were performed in 24 randomly selected fields/lung of each mouse and expressed as the average of eosinophils $/ 10^{4}\left(\mu \mathrm{m}^{2}\right)[22,24]$.

2.5. Cell Recovery from the Airway Lumen, Lung Tissue, Thyme, and Lymph Nodes. For airway lumen, mouse tracheas were cannulated, and bronchoalveolar lavage fluid (BALF) was obtained by gentle aspiration of $0.5 \mathrm{~mL}$ PBS $(1 \mathrm{x},($ Sigma $))$, repeated three times. BALF was centrifuged at $250 \mathrm{~g}$ for 10 minutes at $4^{\circ} \mathrm{C}$, and cell pellets were resuspended in 1x PBS.

For lung tissue, one lung lobe was mechanically chopped and incubated at $37^{\circ} \mathrm{C}$ for $1 \mathrm{~h}$ in RPMI-1640 (Sigma) containing $10 \%$ fetal calf serum (FCS, (Gibco)), plus $0.15 \mathrm{mg}$ / $\mathrm{mL}$ collagenase (type 1 , Gibco) and $25 \mu \mathrm{g} / \mathrm{mL}$ DNAse (type 1, Roche Diagnostics). Cells were recovered by filtration through a $40 \mu \mathrm{m}$ cell strainer, washed 3 times, and resuspended in $5 \mathrm{~mL}$ RPMI $+10 \%$ FCS.

For thyme and lymph nodes, mediastinal lymph nodes (mLN), or total lymph nodes (cervical, axial, and inguinal) were carefully extracted, placed into $1 \mathrm{~mL}$ of $1 \mathrm{x}$ PBS, and homogenized in Potter-Elvehjem (Sigma). Lymph node cells retrieved for cell culture were recovered by filtration through a $40 \mu \mathrm{m}$ cell strainer, washed once, and resuspended in DMEM (Gibco) $+20 \%$ FCS.

Total leucocytes from the BALF, lung digested tissue, thyme, and lymph nodes were counted in a Neubauer chamber after dilution using Turk's solution (2\% acetic acid).

2.6. Detection of Cytokines. Cytokine levels were detected in lung tissue, thymus, or lymph node homogenates. Briefly, tissues were homogenized in the presence of a lysis buffer solution (1x PBS, $0.1 \%$ Triton X-100, and a complete ${ }^{\mathrm{TM}}$ Protease Inhibitor Cocktail tablet (Roche Diagnostics)) and centrifuged $\left(3500 \mathrm{rpm}\right.$ for $10 \mathrm{~min}$ at $4^{\circ} \mathrm{C}$ ), and the resulting supernatant was assayed. Cytokine was also detected from the supernatant of in vitro $\mathrm{T}$ cell assays.

Sandwich ELISAs for IL-5, IL-10, IL-17, IL-33, and TGF$\beta$ were performed as per the manufacturer's instructions (R\&D Systems), as were assayed for IL-4 and IL-13 (Invitro$\operatorname{gen}^{\mathrm{TM}}$ Novex).

2.7. In Vitro T Cell Polarization. Pooled cervical, axial, and inguinal lymph node cells $\left(10^{6} /\right.$ well $)$ from naïve $\mathrm{A} / \mathrm{J}$, $\mathrm{BALB} / \mathrm{c}$, and $\mathrm{C} 57 \mathrm{BL} / 6$ mice were extracted. Cells obtained were exposed to IL-2 (100 UI/mL, Peprotech) alone or with the addition of plate-immobilized anti-CD3e $(2 \mu \mathrm{g} / \mathrm{mL}$, $\mathrm{BD})$, anti-CD28 $(2 \mu \mathrm{g} / \mathrm{mL}, \mathrm{BD})$, and TGF- $\beta(2 \mathrm{ng} / \mathrm{mL}$, 
Peprotech) for $72 \mathrm{~h}$ at $37^{\circ} \mathrm{C}$ and $5 \% \mathrm{CO}_{2}$ [25]. Cells were retrieved for immunophenotyping, and when relevant, supernatant was evaluated for detection of cytokine secretion, as described on the previous section.

mLN cells from OVA-challenged mice were exposed in vitro to IL-2 $(100 \mathrm{UI} / \mathrm{mL})$ alone or with the addition of OVA $(0.5 \mathrm{mg} / \mathrm{mL})$ with or without TGF- $\beta(2 \mathrm{ng} / \mathrm{mL})$ for $72 \mathrm{~h}$ at $37^{\circ} \mathrm{C}$ and $5 \% \mathrm{CO}_{2}$.

2.8. Flow Cytometry Immunophenotyping. Cells were blocked with normal sheep serum and stained with monoclonal anti-mouse CD4 antibodies (RM4-5 clone; eBiosciences; San Diego, CA, USA). Intracellular staining of CD4 T cells was performed using anti-mouse IL-10-PE antibody (JES5-16E3 clone), anti-IL-4 PECy7 (11B11 clone), and anti-IL-17 eFluor 660 (eBio17B7 clone) or the respective controls IgG2b $\kappa$ PE, IgG1 $\kappa$ PECy7, and IgG2a $\kappa$ eFluor 660 (all against mouse proteins, from eBioscience). Treg cells were characterized by staining for CD4, CD25, and Foxp3, according to the manufacturer's instructions (Mouse Treg Staining Kit, eBiosciences).

Pulmonary myeloid dendritic cells $\left(\mathrm{CD} 11 \mathrm{c}^{+} \mathrm{CD} 11 \mathrm{~b}^{+-}\right.$ $\mathrm{Gr}^{-} \mathrm{B} 220^{-}$) were characterized as previously [26], using anti-Gr1 FITC (RB6-8C5 clone) anti-CD11c PE (N418 clone), anti-CD11b PEcy7 (M1/70 clone), and anti-B220 APC (RA3-6B2 clone) or the respective controls IgG2b $\kappa$ FITC, IgG armenian hamster PE, IgG2b $\kappa$ PECy7, and IgG2a $\kappa$ APC (all against mouse proteins, from eBiosciences).

All data were acquired in a FACSCalibur flow cytometer (BD Biosciences Immunocytometry Systems, San Jose, CA, USA) and analyzed using the FlowJo X 10 and 7.6.5 software (Tree Star Inc., Ashland, OR, USA). Percentages of total cells were presented in bar graphs.

2.9. Statistical Analysis. Data were presented as mean standard deviation or median (interquartile range) for a group of 3-10 animals. Statistical analysis was performed using a $t$-test or one-way analysis of variance (ANOVA) followed by Newman-Keuls test. Lung function data were analyzed using two-way ANOVA followed by Bonferroni correction. All tests were performed in GraphPad Prism 6.00 (GraphPad Software, La Jolla, CA, USA). $P$ values $\leq 0.05$ were considered statistically significant.

\section{Results}

Lung resistance was evaluated through whole-body plethysmography where mice were subjected to increasing concentrations of nebulized methacholine, assessed after 4 sequential daily challenges of either OVA or saline. As expected, genetically hyperresponsive A/J mice [27-31] when challenged with OVA showed increased airway resistance compared to the saline-challenged $\mathrm{A} / \mathrm{J}$ mice already with $3 \mathrm{mg} / \mathrm{mL}$ methacholine bronchoprovocation (Figure 1(a)). The increase in airway resistance compared to the same mouse strain challenged with saline was observed in BALB/c mice after the $27 \mathrm{mg} / \mathrm{mL}$ methacholine bronchoprovocation but not in C57BL/6 mice (Figure 1(a)). Analysis of the airway resistance data showed that saline-challenged $\mathrm{A} / \mathrm{J}$ mice presented higher area under the curve (11.3 arbitrary units (AU)), compared to salinechallenged BALB/c (7.1 AU) and C57BL/6 (9.5 AU) mice, as well as when compared to OVA-challenged C57BL/6 mice (10.9 AU), but not to OVA-challenged BALB/c (14.5 AU) or A/J (19.2 AU) mice. Eosinophilic lung infiltration was induced by OVA-challenge in all strains, although it was significantly more pronounced in A/J OVA-challenged mice (Figures 1(b)-1(h)).

After 4 allergenic provocations, OVA-challenged A/J mice presented higher cell counts and percentage of myeloid dendritic cells ( $\mathrm{mDC}$ ) and activated $\mathrm{T}$ cells in the bronchoalveolar lavage fluid (BALF) when compared to A/J salinechallenged (Figures 2(a)-2(c)). The same OVA challenge protocol induced an increase in cell counts, percentage of $\mathrm{mDC}$, and activated $\mathrm{T}$ cells in the airway lumen of BALB/c when compared to their saline-challenge counterpart, which was not observed in C57BL/6 mice (Figures 2(a)-2(c)). Actually, C57BL/6 saline-challenged mice presented more activated $\mathrm{T}$ cells than the other saline-challenged strains, but this percentage was not increased by the allergen challenge (Figure 2(c)). Interestingly, saline-challenged C57BL/ 6 mice were also the ones to present increased percentage of $\mathrm{CD} 4^{+} \mathrm{CD} 25^{+} \mathrm{Foxp}^{+}$regulatory $\mathrm{T}$ cells in the airway lumen (Figure 2(d)). OVA challenge induced an increase in the percentage of these Tregs in the airway lumen of the 3 strains studied (Figure 2(d)).

OVA challenge induced an increase in secretion of Th2 cytokines, such as IL-4, IL-5, IL-13, and IL-33 in the lungs of $\mathrm{A} / \mathrm{J}$ and $\mathrm{BALB} / \mathrm{c}$ mice but not in $\mathrm{C} 57 \mathrm{BL} / 6$ (Figures 3(a)$3(d))$. The increase in IL-13 and IL-33 secretion was more prominent in the lungs of $\mathrm{A} / \mathrm{J}$ OVA-challenged mice than in $\mathrm{BALB} / \mathrm{c}$, whereas $\mathrm{BALB} / \mathrm{c}$ was the one to secrete more IL-4 post-OVA challenge. TGF- $\beta$ secretion was significantly enhanced by OVA challenge in $\mathrm{BALB} / \mathrm{c}$ mice but not in C57BL/6 (Figure 3(e)). Although A/J OVA-challenged mice did not present statistically significant increase in lung TGF$\beta$ levels than the saline-challenged $A / J$, it was higher than levels produced by OVA-challenged C57BL/6 mice (Figure 3(e)). OVA challenge also induced lung secretion of IL-10 in A/J and BALB/c but not in $\mathrm{C} 57 \mathrm{BL} / 6$ mice (Figure 3(f)). Interestingly, A/J saline-challenged mice already presented more IL-10 lung secretion than the other strains (Figure 3(f)). IL-17 lung production was not different in the 3 mouse strains analyzed, independent of the lung challenge used (data not shown).

We investigated the percentage of different subpopulations of CD4 T cells in naïve mice of the 3 strains in different compartments. Naïve A/J mice showed higher percentage of $\mathrm{CD} 4^{+} \mathrm{IL}-4^{+}$and $\mathrm{CD} 4^{+} \mathrm{IL} 10^{+} \mathrm{T}$ cells, compared to the other strains, in the BALF (Figures 4(a) and 4(c)) and in the lungs (Figures $4(\mathrm{e})$ and $4(\mathrm{~g})$ ). There was no significant difference in the percentage of $\mathrm{CD} 4{ }^{+} \mathrm{IL} 17^{+}$and $\mathrm{CD} 4^{+} \mathrm{CD} 25^{+}$Foxp $3^{+}$ cells in the BALF of the 3 strains (Figures $4(\mathrm{~b})$ and $4(\mathrm{~d})$ ). In the digested lungs of $\mathrm{C} 57 \mathrm{BL} / 6$ mice, there was an increased percentage of $\mathrm{CD}^{+} \mathrm{IL}_{1} 7^{+}$cells, compared to $\mathrm{A} / \mathrm{J}$, but again, there was no difference in $\mathrm{CD}^{+} \mathrm{CD} 25^{+}$Foxp $3^{+}$ cells among the strains (Figures $4(\mathrm{f})$ and $4(\mathrm{~h})$ ). There was no difference in $\mathrm{CD} 4^{+} \mathrm{IL}-4^{+}, \mathrm{CD} 4^{+} \mathrm{IL} 17^{+}$, and $\mathrm{CD} 4^{+} \mathrm{IL} 10^{+} \mathrm{T}$ 
(a)

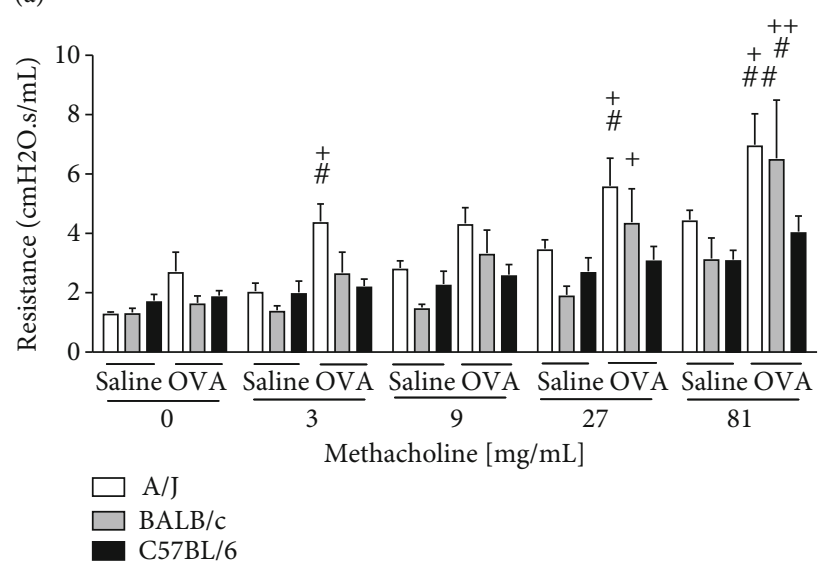

(b)

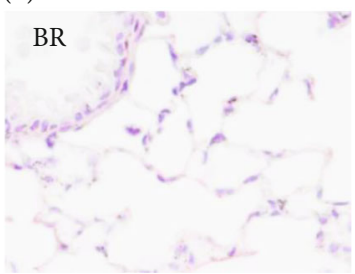

(c)

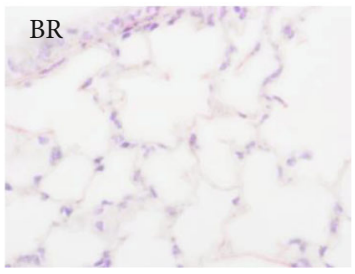

(d)

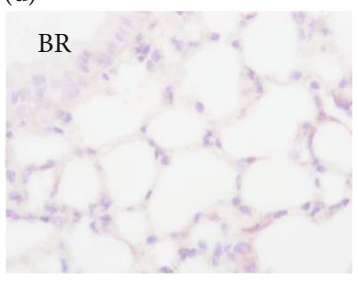

(e)

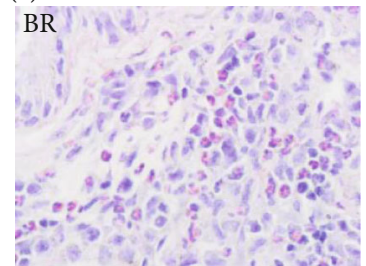

(f)

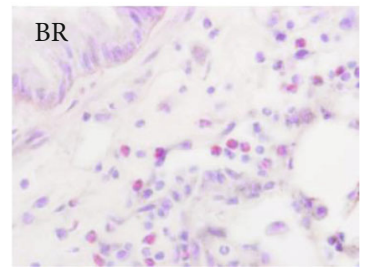

(g)

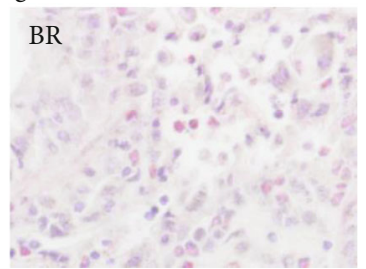

(h)

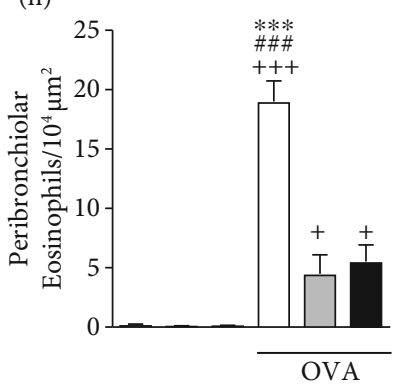

FIGURE 1: Assessment of airway resistance and eosinophilic inflammation in saline or OVA-challenged A/J, BALB/c, or C57BL/6 mice. Lung resistance was induced by increasing concentrations of methacholine bronchoprovocation, evaluated $24 \mathrm{~h}$ after the last OVA challenge (a). Photomicrographs of representative airways stained by Sirius Red of saline-challenged A/J (b), BALB/c (c), or C57BL/6 (d) and OVAchallenged A/J (e), BALB/c (f), or C57BL/6 (g) mice (original magnification 1000x). Quantitative data for eosinophils is shown in (h). Values represent the mean \pm SEM of 4-6 animals per group. ${ }^{+} P<0.05,{ }^{++} P<0.01$, and ${ }^{+++} P<0.001$ as compared to the respective salinechallenged mouse strain group. ${ }^{\#} P<0.05,{ }^{\# \#} P<0.01$, and ${ }^{\# \# \#} P<0.001$ as compared to OVA-challenged C57BL/6 mice. ${ }^{* * *} P<0.001$ as compared to OVA-challenged $\mathrm{BALB} / \mathrm{c}$ mice. 
(a)

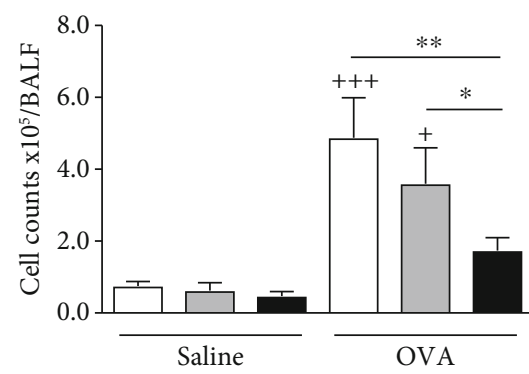

(c)

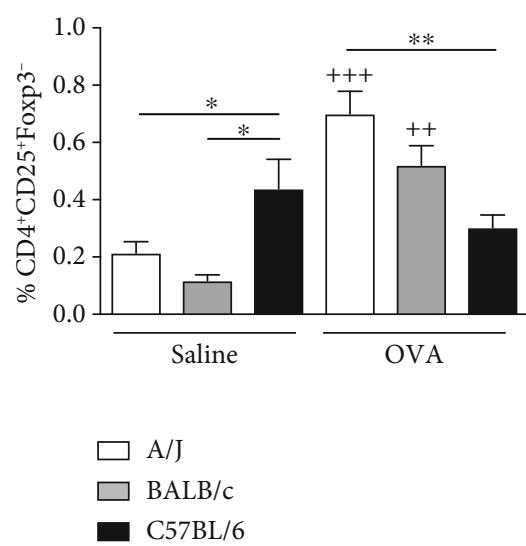

(b)

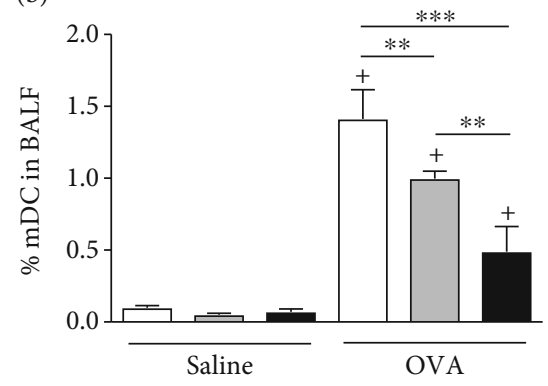

(d)

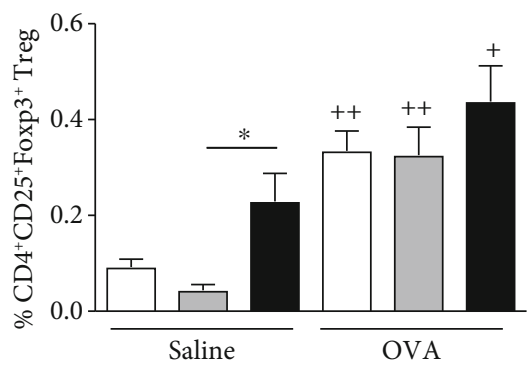

Figure 2: Characterization of inflammatory and regulatory cells in the airways of A/J, BALB/c, and C57BL/6 mice challenged with either OVA or saline. Total leukocyte numbers (a), frequency of pulmonary mDCs (b), CD $4^{+} \mathrm{CD} 25^{+} \mathrm{Foxp} 3^{-}$(c), and CD $4^{+} \mathrm{CD} 25^{+} \mathrm{Foxp} 3^{+} \mathrm{Treg}$ (d) cells in the BALF were evaluated. Values represent mean \pm SEM 4-6 animals per group. ${ }^{+} P<0.05,{ }^{++} P<0.01$, or ${ }^{+++} P<0.001$ as compared to saline-challenged group. ${ }^{*} P<0.05,{ }^{* *} P<0.01$, and ${ }^{* * *} P<0.001$ are comparisons of different OVA-challenged mouse strains.

cells in total lymph nodes of the 3 strains (Figures 4(i), 4(j), and $4(\mathrm{l})$ ), but $\mathrm{A} / \mathrm{J}$ presented less $\mathrm{CD} 4^{+} \mathrm{CD} 25^{+}$Foxp $^{+}$cells than the other strains in these compartments (Figure $4(\mathrm{~m})$ ). Production of TGF- $\beta$ is higher than production of IL-10 in total LNs and thyme of 3 strains of naïve mice analyzed (data not shown). There was no particular strain of naïve mice presenting difference in the production of IL-10 and TGF- $\beta$ in total LNs and thyme (data not shown).

To investigate the expansion of regulatory $\mathrm{T}$ cells in the 3 different strains, total lymph nodes retrieved from naïve mice were antigenically stimulated in vitro in the presence of TGF- $\beta$. Activation of T cells from naïve mice in the presence of TGF- $\beta$ induced expansion of CD $4^{+} \mathrm{CD} 25^{+} \mathrm{Foxp}^{+} \mathrm{T}$ reg cell population in all strains but was significantly higher in cells from BALB/c mice (Figure 5(a)). The same protocol induced significant expansion of $\mathrm{CD} 4^{+} \mathrm{IL} 10^{+}$Treg cells only in $\mathrm{A} / \mathrm{J}$ mice (Figure 5(b)).

Culture of cells from lung draining lymph nodes of OVA-challenged mice with IL-2 showed A/J mice presented higher percentage of $\mathrm{CD} 4^{+} \mathrm{IL} 4^{+} \mathrm{T}$ cells, when compared to $\mathrm{BALB} / \mathrm{c}$ and C57BL/6 mice (Figure 6(a)). The OVA in vitro stimulation of cells from lung draining lymph nodes of OVA-challenged mice did not change much the percentage of $\mathrm{CD} 4^{+} \mathrm{IL} 4^{+} \mathrm{T}$ cells in the 3 different strains. Although the percentage of $\mathrm{CD} 4^{+} \mathrm{IL} 17^{+} \mathrm{T}$ cells from OVA-challenged mouse lung draining lymph nodes maintained by IL-2 in vitro was higher in $\mathrm{BALB} / \mathrm{c}$ mice, compared to $\mathrm{C} 57 \mathrm{BL} / 6$, this difference reduced when cells were stimulated with OVA in vitro (Figure 6(b)). Culture of cells from lung draining lymph nodes of OVA-challenged mice with IL-2 showed $\mathrm{BALB} / \mathrm{c}$ presented higher percentage of $\mathrm{CD} 4^{+} \mathrm{CD} 25^{+} \mathrm{Foxp} 3^{+}$ Treg cells. After the in vitro antigenic stimulus with OVA, there was a very significant increase in the percentage of $\mathrm{CD} 4{ }^{+} \mathrm{CD} 25^{+} \mathrm{Foxp}^{+}{ }^{+}$Treg cells from C57BL/6 mouse cells when compared to $\mathrm{A} / \mathrm{J}$ and $\mathrm{BALB} / \mathrm{c}$ (Figure $6(\mathrm{c})$ ). Addition of TGF- $\beta$ with the OVA in vitro stimulus favored an increase in the percentage of $\mathrm{CD} 4^{+} \mathrm{CD} 25^{+}$Foxp $3^{+}$Treg cells from all strains analyzed, but their percentage kept higher when cells came from OVA activated C57BL/6 mice (Figure 6(c)). After in vitro IL-2 stimulation of OVAchallenged mouse lung draining lymph node cells, A/J mice presented higher percentage of $\mathrm{CD}^{+} \mathrm{IL} 10^{+}$cells, compared to $\mathrm{BALB} / \mathrm{c}$ and $\mathrm{C} 57 \mathrm{BL} / 6$ mice (Figure $6(\mathrm{~d})$ ). OVA activation led to a further increase in the percentage of $\mathrm{CD} 4^{+} \mathrm{IL} 10^{+} \mathrm{T}$ cells from A/J mice, which was maintained in the presence of TGF- $\beta$ (Figure 6(d)). Accordingly, in vitro production of IL-10 from cells obtained from A/J OVA-challenged mice, either stimulated with OVA or OVA and TGF- $\beta$, was higher than in supernatants of cells obtained from $\mathrm{BALB} / \mathrm{c}$ or C57BL/6 OVA-challenged mice (Figure 6(e)). The percentage of $\mathrm{CD}^{+} \mathrm{IL}_{10}{ }^{+} \mathrm{T}$ cells correlated positively with the production of IL-10 in cultures of A/J OVA-challenged mouse cells in the presence of IL-2, OVA, and TGF- $\beta$ (Figure 6(f 
(a)

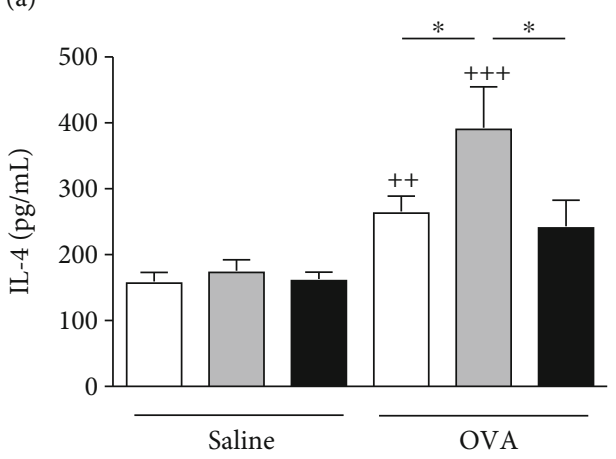

(c)

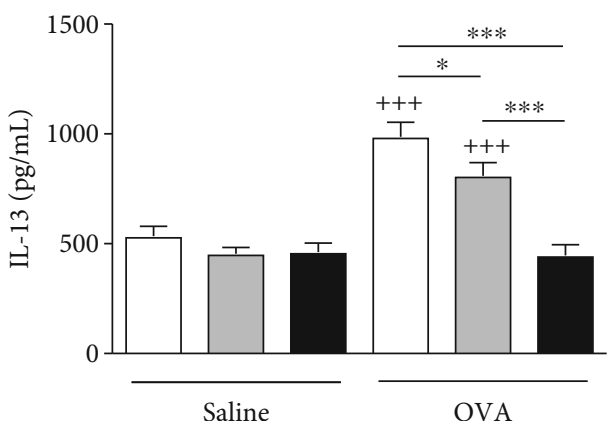

(e)

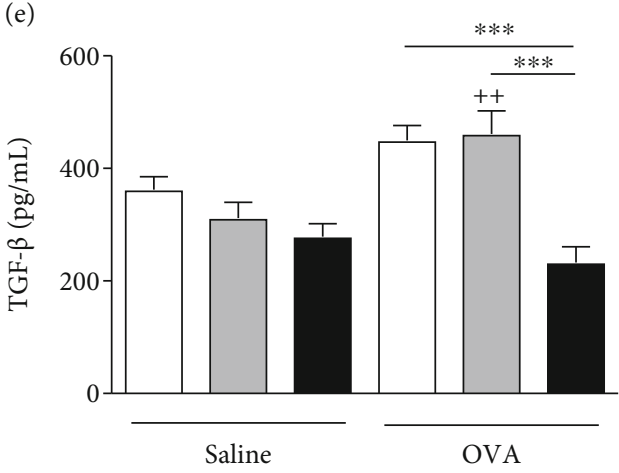

(b)

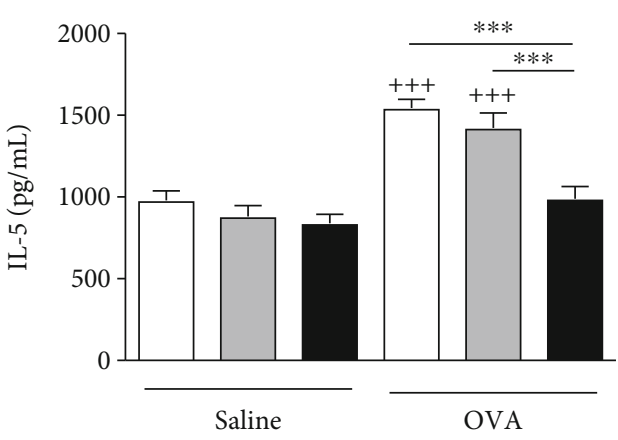

(d)

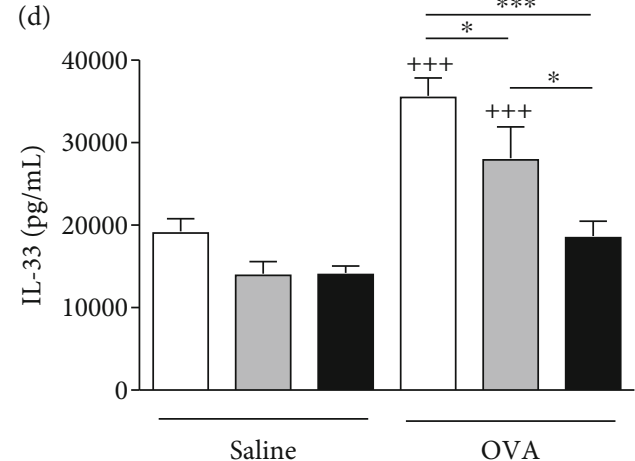

(f)

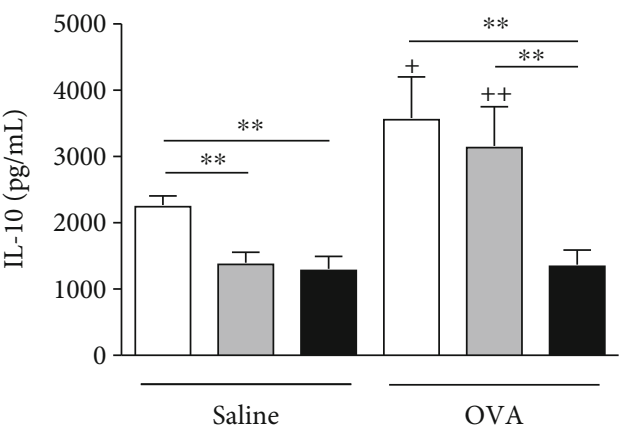

$\square \mathrm{A} / \mathrm{J}$
$\square \mathrm{BALB} / \mathrm{c}$
$\mathrm{C} 57 \mathrm{BL} / 6$

FIgure 3: Production of Th2 and anti-inflammatory cytokines in the lung tissue of A/J, BALB/c, and C57BL/6 mice challenged with either OVA or saline. Detection of cytokines IL-4 (a), IL-5 (b), IL-13 (c), IL-33 (d), TGF- $\beta$ (e), and IL-10 (f) in the lung homogenate by ELISA. Values represent mean \pm SEM of 5-6 animals per group. ${ }^{+} P<0.05$ as compared to saline-challenged group. ${ }^{++} P<0.01$ and ${ }^{+++} P<0.001$ as compared to saline-challenged group. ${ }^{*} P<0.05,{ }^{* *} P<0.01$, and ${ }^{* * *} P<0.001$ are comparisons of different OVA-challenged mouse strains.

)). This correlation was not observed in cells obtained from $\mathrm{BALB} / \mathrm{c}$ or $\mathrm{C} 57 \mathrm{BL} / 6$ mice.

\section{Discussion}

This study is aimed at investigating the differences in frequencies of Treg cell subtypes among naïve $\mathrm{A} / \mathrm{J}, \mathrm{BALB} / \mathrm{c}$, and C57BL/6 mice and following allergenic stimulation with OVA in vivo and in vitro. Our results showed that C57BL/6 mice presented the highest lung levels of $\mathrm{CD} 4{ }^{+} \mathrm{CD} 25^{+-}$ Foxp $3^{+}$cells in the presence or absence of allergen provoca- tion and failed to develop asthma characteristic features following allergen provocation. Additionally, the in vitro OVA allergenic challenge led to a pronounced increase in the percentage of $\mathrm{CD} 4^{+} \mathrm{CD} 25^{+} \mathrm{Foxp}^{+}$cells from $\mathrm{C} 57 \mathrm{BL} / 6$ mice, compared to the other strains. $\mathrm{A} / \mathrm{J}$ and $\mathrm{BALB} / \mathrm{c}$ mice developed characteristic lung inflammation and AHR with the OVA lung challenge, accompanied by a TGF- $\beta$-dependent increase in the levels of $\mathrm{CD}^{+} \mathrm{CD} 25^{+} \mathrm{Foxp}^{+}$cells in vitro. Naïve $\mathrm{A} / \mathrm{J}$ mice presented higher percentage of $\mathrm{CD} 4^{+} \mathrm{IL} 10^{+}$cells in the lungs, when compared to the other strains. Although OVA-challenged-A/J mice presented 
(a)

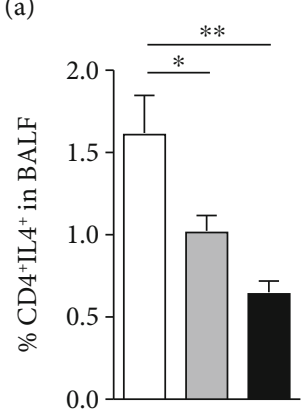

(e)

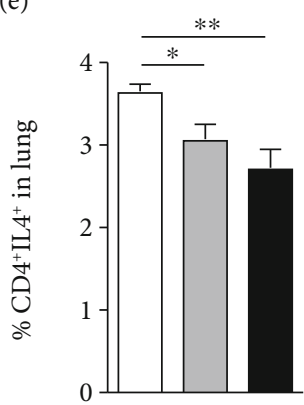

(i)
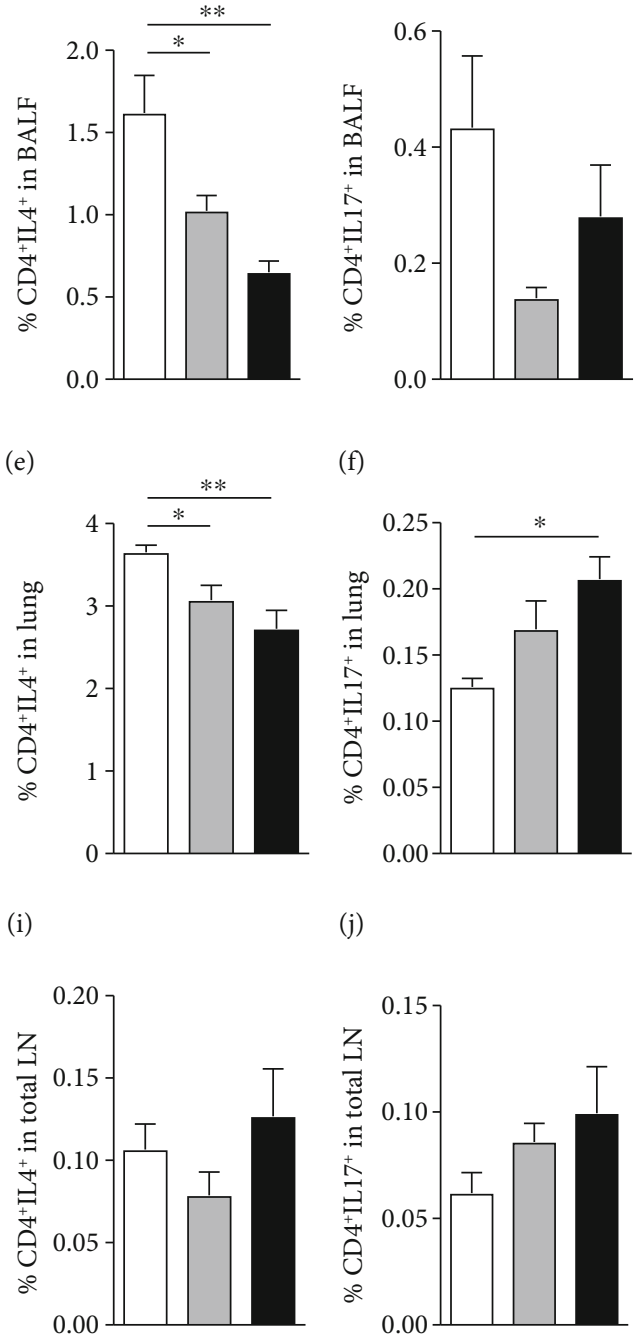

(f)

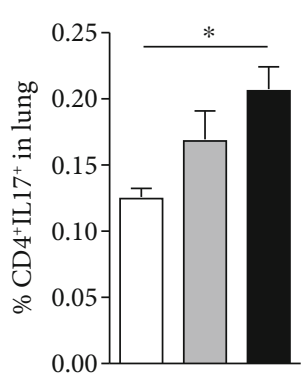

(j)

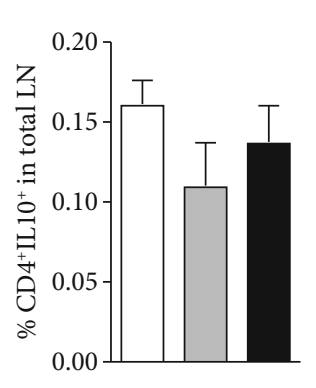

(k) (c)

(d)
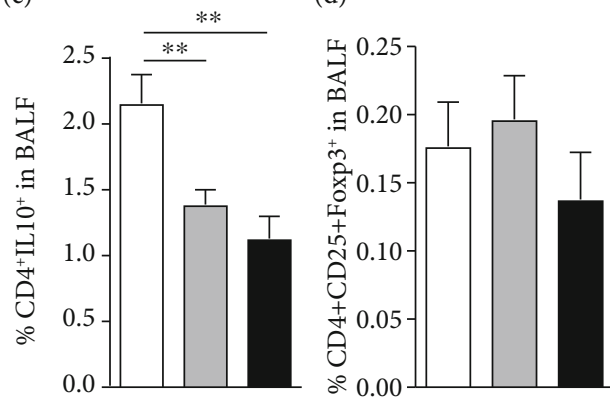

(g)

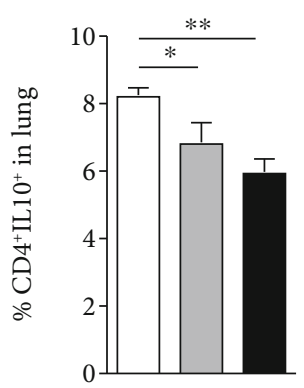

(h)

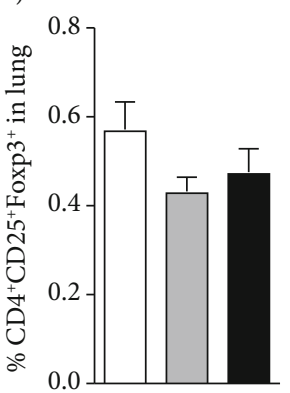

(1)

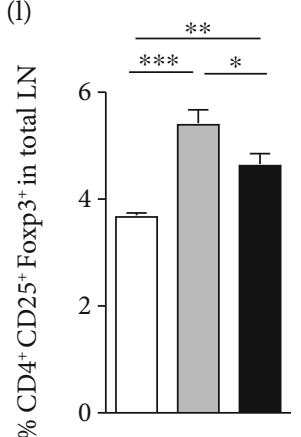

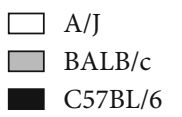


(a)

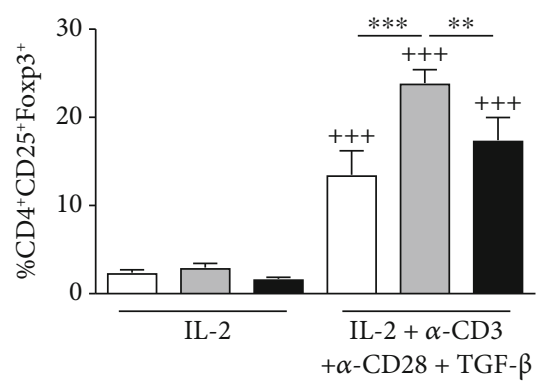

(b)

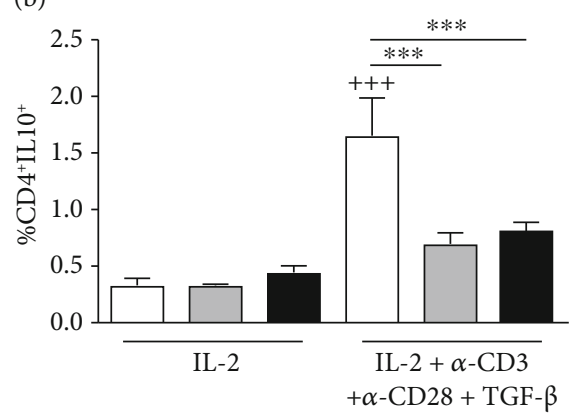

Figure 5: In vitro expansion of $\mathrm{CD} 4^{+} \mathrm{CD} 25^{+} \mathrm{Foxp} 3^{+}$and $\mathrm{CD} 4^{+} \mathrm{IL} 10^{+}$cell populations from lymph nodes of A/J, BALB/c, or C57BL/6 naive mice. Cells from cervical, axillary, and inguinal lymph nodes were cultured for $72 \mathrm{~h}$ in the presence of IL- 2 or IL- $2+\mathrm{TGF}-\beta+$ anti-CD3 + anti-CD28, and subpopulations of $\mathrm{CD}^{+} \mathrm{CD} 25^{+} \mathrm{Foxp}^{+}$(a) or CD4 ${ }^{+} \mathrm{IL}-10^{+}$(b) were analyzed by flow cytometry. Values represent mean \pm SEM of 4-5 animals per group. ${ }^{+++} P<0.001$ as compared to the same mouse strain cells that received only IL-2. ${ }^{* *} P<0.01$ and ${ }^{* * *} P$ $<0.001$ are comparisons of different mouse strains stimulated with IL- $2+$ TGF- $\beta+$ anti-CD3 + anti-CD28.

cytokines in the lungs in allergic asthma, AHR and lung secretion of IL-4 and IL-5 induced by OVA was increased in both $\mathrm{A} / \mathrm{J}$ and BALB/c. The role of Th17 cells in allergic asthma is less clear than Th2 cells; experimental models have shown IL-17 to exert both anti-inflammatory and proneutrophilic inflammatory effects, indicating distinct activities in sensitization and challenge phases [36]. Here, A/J naïve mice presented reduced frequency of Th17 cells in the lungs, compared to C57BL/6, but IL-17 lung production was not different in the 3 mouse strains after the antigenic challenge.

The role of Foxp $3^{+}$Tregs in asthmatic patients is also a matter of controversy; it has been shown that adult patients with severe symptoms present low amounts of Tregs in the airways and blood $[13,14]$, while other studies show the number of lung regulatory lymphocytes to be increased in severe asthma compared with mild asthmatics and healthy subjects [16], especially following inhaled allergen challenge [17]. In mice, inhalation of OVA leads to tolerance mediated by Foxp $3^{+}$Tregs [37], unless it is administered with an adjuvant combined with priming through subcutaneous or intraperitoneal routes. Different models of experimental asthma using OVA combined with an adjuvant can induce lung inflammation and AHR, mimicking the main features of the disease. Data on the frequency of Foxp3 Treg cells in murine experimental asthma are not easily compared, since they either lack nonallergic control mice and Foxp3 intracellular staining on $\mathrm{CD} 4^{+} \mathrm{CD} 25^{+}$cells or use only one mouse strain $[23,38,39]$. Nonetheless, the immunosuppressive role of these cells has been confirmed, since transfer of Tregs can suppress the main features of asthma in mice, through secretion of IL-10 and TGF- $\beta$ [26]. In our study, C57BL/6 mice did not develop lung inflammation or AHR with the allergenic protocol used, which could be a consequence of the higher frequency of Foxp $3^{+}$Tregs in their airways and of the higher expansion of these cells upon an OVA in vitro booster, compared to cells from the other strains. On the other hand, OVA-challenged A/J mice presented robust lung inflammation and AHR, but Foxp ${ }^{+}$Treg cells obtained from their lung draining lymph nodes did not expand in the presence of OVA in vitro and had limited expansion when OVA was used with TGF- $\beta$, an inducer of Treg cell generation and expansion $[25,40]$. Nonallergic in vitro stimulus of naïve lymph node cells with anti-CD3 and anti-CD28 in the presence of TGF- $\beta$ led to an increased expansion of the $\mathrm{CD} 4^{+} \mathrm{CD} 25^{+}$Foxp $3^{+}$cell population in cells obtained from all mice, but this increase was significantly higher in cells from BALB/c mice, compared to $\mathrm{A} / \mathrm{J}$ and $\mathrm{C} 57 \mathrm{BL} / 6$. Interestingly, when cells are obtained from the lung draining lymph nodes of OVA-challenged mice, BALB/c presented higher frequency of the $\mathrm{CD} 4^{+} \mathrm{CD} 25^{+} \mathrm{Foxp} 3^{+}$cell population, but upon an OVA antigenic in vitro booster, there was a clear increase in the frequency of $\mathrm{CD} 4^{+} \mathrm{CD} 25^{+} \mathrm{Foxp}^{+}$cell population in cells from $\mathrm{C} 57 \mathrm{BL} / 6$ mice. An in vitro study using human CD4 T cells showed enhancement of Foxp3 expression induced by $1 \alpha 25 \mathrm{VitD} 3$ that can be impaired by IL-10 [41]. It is possible, therefore, that the difference in the frequency of $\mathrm{CD} 4^{+} \mathrm{CD} 25^{+} \mathrm{Foxp}^{+}$cells among the OVA-challenged strains is a consequence of the levels of IL-10 secreted, since A/J mice present high levels of IL-10 and smaller frequency of Foxp $3^{+}$Tregs.

In our study, naïve $\mathrm{A} / \mathrm{J}$ mice presented higher frequency of $\mathrm{CD} 4^{+} \mathrm{IL}-10^{+}$cells in the lung parenchyma and airways, when compared to $\mathrm{BALB} / \mathrm{C}$ and $\mathrm{C} 57 \mathrm{BL} / 6$ naïve animals. OVA-sensitized and saline-challenged A/J mice also presented higher IL-10 production in the lungs, compared to the other strains. OVA lung challenge further increased lung IL-10 production in both $\mathrm{A} / \mathrm{J}$ and $\mathrm{BALB} / \mathrm{c}$ mice but not in $\mathrm{C} 57 \mathrm{BL} / 6$. Allergenic in vitro booster of $\mathrm{A} / \mathrm{J}$ mouse mediastinal lymph node cells obtained from OVA-challenged mice led to a significant increase in percentage of $\mathrm{CD} 4^{+} \mathrm{IL}-10^{+}$ cells, showing these cells are responsive to OVA. Additionally, the increase in the frequency of $\mathrm{CD} 4^{+} \mathrm{IL}-10^{+}$cells correlated with enhanced IL-10 production in vitro, suggesting these cells are responsible, at least in part, for the IL-10 increased production in $\mathrm{A} / \mathrm{J}$ mouse. Domínguez-Punaro and cols assessed the response to Streptococcus suis in 
(a)

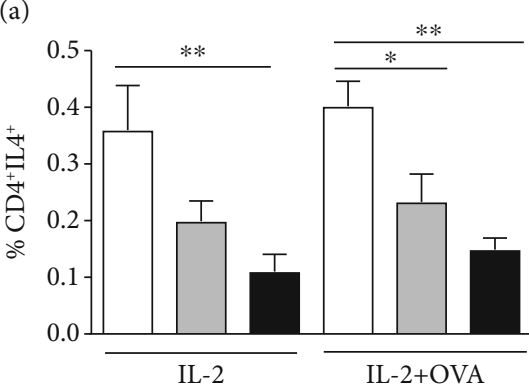

(c)

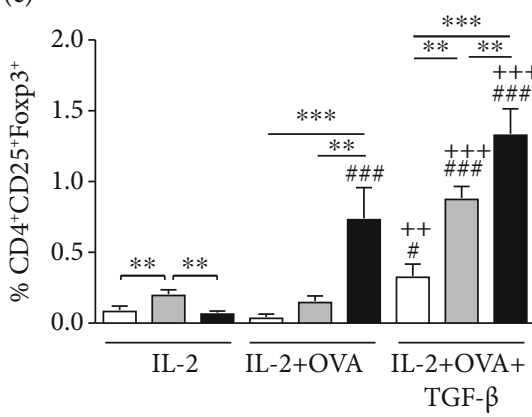

(e)

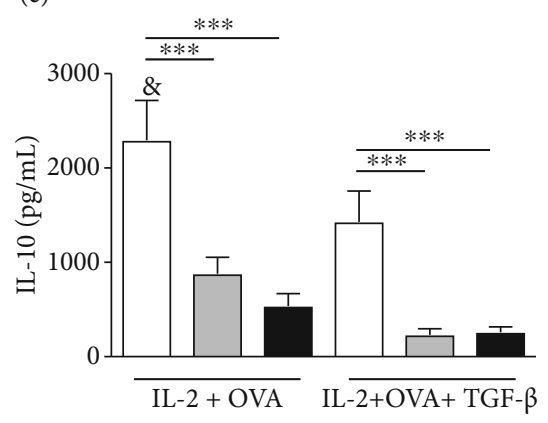

(b)

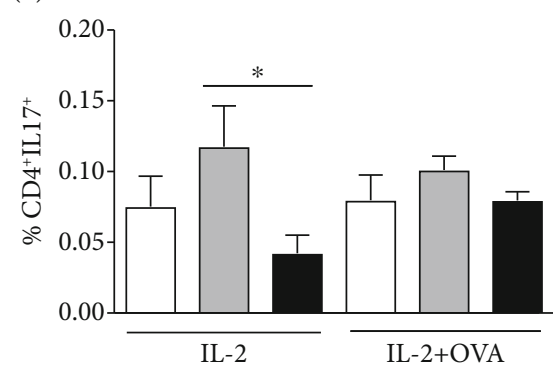

(d)

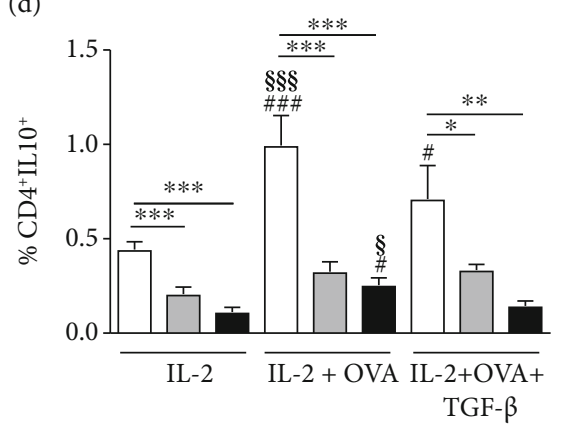

(f)

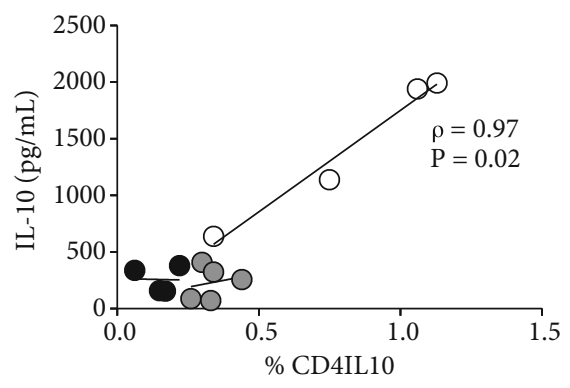

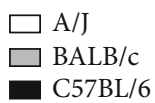

FIGURE 6: In vitro expansion of $\mathrm{CD} 4^{+} \mathrm{IL} 4^{+}, \mathrm{CD} 4^{+} \mathrm{IL} 17^{+}, \mathrm{CD} 4^{+} \mathrm{CD} 25^{+} \mathrm{Foxp} 3^{+}$, and $\mathrm{CD} 4^{+} \mathrm{IL} 10^{+}$cell populations from lymph nodes of $\mathrm{A} / \mathrm{J}$, $\mathrm{BALB} / \mathrm{c}$, or C57BL/6 OVA-challenged mice. Cells from mediastinal lymph nodes were cultured for $72 \mathrm{~h}$ in the presence IL-2, IL-2 + OVA, or IL- $2+$ OVA + TGF- $\beta$, and subpopulations of CD4 ${ }^{+} \mathrm{IL} 4^{+}$(a) and CD $4^{+} \mathrm{IL}_{17}{ }^{+}$(b) $\mathrm{CD} 4^{+} \mathrm{CD} 25^{+} \mathrm{Foxp} 3^{+}$(c) or CD4 ${ }^{+} \mathrm{IL} 10^{+}$(d) were analyzed by flow cytometry. IL-10 production in the supernatant of cultured cells was detected by ELISA (e). Values represent mean \pm SEM of 4-5 animals per group. ${ }^{\#} P<0.05$ and ${ }^{\# \# \#} P<0.001$ as compared to the same mouse strain group that received only IL-2. ${ }^{++} P<0.01$ and ${ }^{+++} P<0.001$ as compared to the same mouse strain group that received IL-2+OVA. ${ }^{\$} P<0.05$ and ${ }^{\$ \$ \$} P<0.001$ as compared to the same mouse strain group that received IL- $2+\mathrm{OVA}+\mathrm{TGF}-\beta .{ }^{8} P<0.05$ as compared to the same strain between different stimulus. ${ }^{*} P<0.05,{ }^{* *} P<0.01,{ }^{* * *} P<0.001$. Correlation between frequency of $\mathrm{CD} 44^{+} \mathrm{IL} 10^{+}$cells and IL- 10 production in cultures stimulated with OVA and TGF- $\beta$ (f). Pseudo- $r=0.97, P=0.02$ by univariate analysis.

different mouse strains and demonstrated that $\mathrm{A} / \mathrm{J}$ mice had increased susceptibility to the disease due to an increased inflammatory response, when compared to C57BL/6 mice [42]. In their model, enhanced production of IL-10 in C57BL/6 infected mice was associated to their higher survival. They also provided evidence that the IL-10 treatment of $\mathrm{A} / \mathrm{J}$ infected mice had protective effect, pointing out that $\mathrm{A} / \mathrm{J}$ mice are responsive to IL-10, and this cytokine may have a role in the susceptibility to this inflammatory condition.

Although there are still no data showing unresponsiveness to IL-10 in A/J mice, we cannot rule out possible disfunctions on the IL-10, IL-10 receptor (IL-10R), or the downstream signaling pathway. Polymorphisms of IL-10, IL-10R, and STAT3, a Janus kinase (JAK)-signal transducer and activator of transcription, activated downstream of IL10R were found to be associated to asthma and higher levels of IgE, without interfering with IL-10 levels [43, 44]. Nonetheless, IL-10 production is sustained by IL-10R in mouse and human Tregs [45], suggesting that $\mathrm{CD} 4^{+} \mathrm{IL} 10^{+}$cells are responsive to IL-10 in A/J mice. Moreover, IL-10 displays pleiotropic effects in key inflammatory cells of asthma; for instance, it was described to have distinct roles in IgE production, either inhibiting $\operatorname{IgE}$ switching or potentiating $\operatorname{IgE}$ production on IgE isotype switched cells $[46,47]$. A dual role 
of IL-10 on the production of IL-5 and IL-13 was also described; interestingly, upregulation of Th2 cytokines was found when overexpression of IL-10 was induced during the late immune response [48]. If Th2 cytokine and IgE increased production on allergenic-challenged $\mathrm{A} / \mathrm{J}$ mice $[32,33]$ is linked to their higher levels of the lung secreted, IL-10 is still a matter that needs further investigation.

In conclusion, the present study suggests that the observed differences in the frequencies of allergenresponsive Foxp3 or IL-10 CD4 T cells are associated with the distinct susceptibility of $\mathrm{A} / \mathrm{J}, \mathrm{BALB} / \mathrm{c}$, and $\mathrm{C} 57 \mathrm{BL} / 6$ mice to experimental asthma. These characteristics are crucial and should be considered upon choosing a mouse strain to study difficulty-to-treat asthma and to screen novel antiasthma candidate compounds.

\section{Data Availability}

Data available on request from the authors.

\section{Additional Points}

Key Messages. Foxp3 or IL-10 Tregs have distinct frequencies in different mouse strains. Differences in allergenresponsive Treg frequencies are associated with distinct susceptibility to experimental asthma. These characteristics should be considered upon choosing a mouse strain to study asthma and antiasthmatics.

\section{Ethical Approval}

All procedures involving the care and use of mice were examined and approved by the appropriate Animal Ethics Committee.

\section{Conflicts of Interest}

There are no conflicts of interest for all named author.

\section{Authors' Contributions}

C.T. Azevedo, A.C. Cotias, A.C.S. Arantes, T.P.T. Ferreira, and P.C. Olsen performed experiments and analyzed the data. M.A. Martins and P.C. Olsen designed the laboratory studies and analyzed the data. C.T. Azevedo, M.A. Martins, and P.C. Olsen wrote the initial draft of the manuscript, and all of the authors reviewed and contributed to the final version. M.A. Martins and P.C. Olsen contributed equally to this work.

\section{Acknowledgments}

The authors would like to express their gratitude to Mrs. Ana Lucia Pires Loureiro for her technical assistance during the experiments. This study was supported by the Brazilian Council for Scientific and Technological Development $(\mathrm{CNPq})$ and the Rio de Janeiro State Research Foundation (FAPERJ). A.C. Cotias was supported by a CAPES Fellowship. A.C.S. Arantes and T.P.T. Ferreira were supported by fellowships from FAPERJ.

\section{References}

[1] D. T. Umetsu and R. H. DeKruyff, "The regulation of allergy and asthma," Immunological Reviews, vol. 212, no. 1 , pp. 238-255, 2006.

[2] M. A. Curotto de Lafaille, J. J. Lafaille, and L. Graça, "Mechanisms of tolerance and allergic sensitization in the airways and the lungs," Current Opinion in Immunology, vol. 22, no. 5, pp. 616-622, 2010.

[3] W. Duan and M. Croft, "Control of regulatory T cells and airway tolerance by lung macrophages and dendritic cells," Annals ATS, vol. 11, Supplement 5, pp. S306-S313, 2014.

[4] S. Sakaguchi, T. Takahashi, and Y. Nishizuka, "Study on cellular events in post-thymectomy autoimmune oophoritis in mice. II. Requirement of Lyt-1 cells in normal female mice for the prevention of oophoritis," The Journal of Experimental Medicine, vol. 156, no. 6, pp. 1577-1586, 1982.

[5] S. Sakaguchi, N. Sakaguchi, M. Asano, M. Itoh, and M. Toda, "Immunologic self-tolerance maintained by activated $\mathrm{T}$ cells expressing IL-2 receptor alpha-chains (CD25). Breakdown of a single mechanism of self-tolerance causes various autoimmune diseases," The Journal of Immunology, vol. 155, no. 3, pp. 1151-1164, 1995.

[6] S. Hori, T. Nomura, and S. Sakaguchi, "Control of regulatory T cell development by the transcription factor Foxp3," Science, vol. 299, no. 5609, pp. 1057-1061, 2003.

[7] J. D. Fontenot, M. A. Gavin, and A. Y. Rudensky, "Foxp3 programs the development and function of $\mathrm{CD} 4^{+} \mathrm{CD} 25^{+}$regulatory T cells," Nature Immunology, vol. 4, no. 4, pp. 330-336, 2003.

[8] M. Noval Rivas and T. A. Chatila, "Regulatory T cells in allergic diseases," Journal of Allergy and Clinical Immunology, vol. 138, no. 3, pp. 639-652, 2016.

[9] A. Taylor, M. Akdis, A. Joss et al., "IL-10 inhibits CD28 and ICOS costimulations of T cells via src homology 2 domaincontaining protein tyrosine phosphatase 1," Journal of Allergy and Clinical Immunology, vol. 120, no. 1, pp. 76-83, 2007.

[10] L. Schandené, C. Alonso-Vega, F. Willems et al., "B7/CD28dependent IL-5 production by human resting T cells is inhibited by IL-10," Journal of Immunology, vol. 152, pp. 43684374, 1994.

[11] M. Pierkes, I. Bellinghausen, T. Hultsch, G. Metz, J. Knop, and J. Saloga, "Decreased release of histamine and sulfidoleukotrienes by human peripheral blood leukocytes after wasp venom immunotherapy is partially due to induction of IL-10 and IFN- $\gamma$ production of T cells," Journal of Allergy and Clinical Immunology, vol. 103, no. 2, pp. 326-332, 1999.

[12] G. Gri, S. Piconese, B. Frossi et al., "CD $4{ }^{+} \mathrm{CD} 25^{+}$regulatory T cells suppress mast cell degranulation and allergic responses through OX40-OX40L interaction," Immunity, vol. 29, no. 5, pp. 771-781, 2008.

[13] A. Barczyk, W. Pierzchala, G. Caramori et al., "Decreased percentage of $\mathrm{CD}^{+}$Foxp $3^{+}$TGF- $\beta^{+}$and increased percentage of $\mathrm{CD} 4^{+} \mathrm{IL}-17^{+}$cells in bronchoalveolar lavage of asthmatics," Journal of Inflammation, vol. 11, no. 1, p. 22, 2014.

[14] E. Mamessier, A. Nieves, A. M. Lorec et al., "T-cell activation during exacerbations: a longitudinal study in refractory asthma," Allergy, vol. 63, no. 9, pp. 1202-1210, 2008.

[15] D. Hartl, B. Koller, A. T. Mehlhorn et al., "Quantitative and functional impairment of pulmonary $\mathrm{CD} 4{ }^{+} \mathrm{CD} 25^{\text {hi }}$ regulatory $\mathrm{T}$ cells in pediatric asthma," Journal of Allergy and Clinical Immunology, vol. 119, no. 5, pp. 1258-1266, 2007. 
[16] L. J. C. Smyth, A. Eustace, U. Kolsum, J. Blaikely, and D. Singh, "Increased airway T regulatory cells in asthmatic subjects," Chest, vol. 138, no. 4, pp. 905-912, 2010.

[17] S. Thunberg, G. Gafvelin, M. Nord et al., "Allergen provocation increases TH2-cytokines and FOXP3 expression in the asthmatic lung," Allergy, vol. 65, no. 3, pp. 311-318, 2010.

[18] N. Joller, E. Lozano, P. R. Burkett et al., “Treg cells expressing the coinhibitory molecule TIGIT selectively inhibit proinflammatory Th1 and Th17 cell responses," Immunity, vol. 40, no. 4, pp. 569-581, 2014.

[19] M. C. Pereira-Santos, A. P. Baptista, A. Melo et al., "Expansion of circulating Foxp $3^{+} \mathrm{D} 25^{\text {bright }} \mathrm{CD} 4^{+} \mathrm{T}$ cells during specific venom immunotherapy," Clinical \& Experimental Allergy, vol. 38, no. 2, pp. 291-297, 2008.

[20] S. Radulovic, M. R. Jacobson, S. R. Durham, and K. T. NouriAria, "Grass pollen immunotherapy induces Foxp3-expressing $\mathrm{CD} 4{ }^{+} \mathrm{CD} 25^{+}$cells in the nasal mucosa," Journal of Allergy and Clinical Immunology, vol. 121, no. 6, pp. 1467-1472.e1, 2008.

[21] R. E. O'Hehir, L. M. Gardner, M. P. de Leon et al., "House dust mite sublingual immunotherapy," American Journal of Respiratory and Critical Care Medicine, vol. 180, no. 10, pp. 936947, 2009.

[22] M. F. Serra, A. C. Cotias, C. R. R. Pão et al., "Repeated allergen exposure in A/J mice causes steroid-insensitive asthma via a defect in glucocorticoid receptor bioavailability," The Journal of Immunology, vol. 201, no. 3, pp. 851-860, 2018.

[23] P. C. Olsen, T. P. T. Ferreira, M. F. Serra et al., "Lidocainederivative JMF2-1 prevents ovalbumin-induced airway inflammation by regulating the function and survival of $\mathrm{T}$ cells," Clinical \& Experimental Allergy, vol. 41, no. 2, pp. 250-259, 2011.

[24] D. K. Meyerholz, M. A. Griffin, E. M. Castilow, and S. M. Varga, "Comparison of histochemical methods for murine eosinophil detection in an RSV vaccine-enhanced inflammation model," Toxicologic Pathology, vol. 37, no. 2, pp. 249255, 2009.

[25] W. Chen, W. Jin, N. Hardegen et al., "Conversion of peripheral CD4+CD25- naive T cells to CD4+CD25+ regulatory T cells by TGF- $\beta$ induction of transcription factor Foxp3," Journal of Experimental Medicine, vol. 198, no. 12, pp. 1875-1886, 2003.

[26] I. P. Lewkowich, N. S. Herman, K. W. Schleifer et al., "CD4 $+\mathrm{CD} 25+\mathrm{T}$ cells protect against experimentally induced asthma and alter pulmonary dendritic cell phenotype and function," Journal of Experimental Medicine, vol. 202, no. 11, pp. 1549-1561, 2005.

[27] M. A. Antunes, S. C. Abreu, N. R. Damaceno-Rodrigues et al., "Different strains of mice present distinct lung tissue mechanics and extracellular matrix composition in a model of chronic allergic asthma," Respiratory Physiology \& Neurobiology, vol. 165, no. 2-3, pp. 202-207, 2009.

[28] G. T. de Sanctis, M. Merchant, D. R. Beier et al., "Quantitative locus analysis of airway hyperresponsiveness in $\mathrm{A} / \mathrm{J}$ and C57BL/6J mice," Nature Genetics, vol. 11, no. 2, pp. 150-154, 1995.

[29] S. L. Ewart, W. Mitzner, D. A. DiSilvestre, D. A. Meyers, and R. C. Levitt, "Airway hyperresponsiveness to acetylcholine: segregation analysis and evidence for linkage to murine chromosome 6," American Journal of Respiratory Cell and Molecular Biology, vol. 14, no. 5, pp. 487-495, 1996.

[30] M. WILLS-KARP and S. . L. EWART, "The genetics of allergen-induced airway hyperresponsiveness in mice," Amer- ican Journal of Respiratory and Critical Care Medicine, vol. 156, no. 4, pp. S89-S96, 1997.

[31] H. Hadeiba, D. B. Corry, and R. M. Locksley, "Baseline airway hyperreactivity in A/J mice is not mediated by cells of the adaptive immune system," Journal of Immunology, vol. 164, no. 9, pp. 4933-4940, 2000.

[32] V. de Vooght, J. A. J. Vanoirbeek, K. Luyts, S. Haenen, B. Nemery, and P. H. M. Hoet, "Choice of mouse strain influences the outcome in a mouse model of chemical-induced asthma," PLoS One, vol. 5, no. 9, article e12581, 2010.

[33] K. Shinagawa and M. Kojima, "Mouse model of airway remodeling," American Journal of Respiratory and Critical Care Medicine, vol. 168, no. 8, pp. 959-967, 2003.

[34] H. J. de Heer, H. Hammad, T. Soullié et al., "Essential role of lung plasmacytoid dendritic cells in preventing asthmatic reactions to harmless inhaled antigen," Journal of Experimental Medicine, vol. 200, no. 1, pp. 89-98, 2004.

[35] D. A. Kuperman, X. Huang, L. L. Koth et al., "Direct effects of interleukin-13 on epithelial cells cause airway hyperreactivity and mucus overproduction in asthma," Nature Medicine, vol. 8, no. 8, pp. 885-889, 2002.

[36] B. N. Lambrecht and H. Hammad, "The immunology of asthma," Nature Immunology, vol. 16, no. 1, pp. 45-56, 2015.

[37] M. Ostroukhova, C. Seguin-Devaux, T. B. Oriss et al., “Tolerance induced by inhaled antigen involves CD4+ T cells expressing membrane-bound TGF- $\beta$ and FOXP3," The Journal of Clinical Investigation, vol. 114, no. 1, pp. 28-38, 2004.

[38] K. Matsumoto, H. Inoue, S. Fukuyama et al., "Frequency of Foxp $3^{+} \mathrm{CD} 4^{+} \mathrm{CD} 25^{+} \mathrm{T}$ cells is associated with the phenotypes of allergic asthma," Respirology, vol. 14, no. 2, pp. 187-194, 2009.

[39] C.-C. Lin, Y. Y. Wang, S. M. Chen et al., "Shegan-Mahuang Decoction ameliorates asthmatic airway hyperresponsiveness by downregulating Th2/Th17 cells but upregulating CD4 +FoxP3+ Tregs," Journal of Ethnopharmacology, vol. 253, p. 112656, 2020.

[40] Y. Y. Wan and R. A. Flavell, "Regulatory T-cell functions are subverted and converted owing to attenuated Foxp3 expression," Nature, vol. 445, no. 7129, pp. 766-770, 2007.

[41] Z. Urry, E. S. Chambers, E. Xystrakis et al., "The role of $1 \alpha, 25-$ dihydroxyvitamin D3 and cytokines in the promotion of distinct Foxp $3^{+}$and IL- $10^{+} \mathrm{CD} 4^{+} \mathrm{T}$ cells," European Journal of Immunology, vol. 42, no. 10, pp. 2697-2708, 2012.

[42] M.. . . C. Domínguez-Punaro, M. Segura, D. Radzioch, S. Rivest, and M. Gottschalk, "comparison of the susceptibilities of C57BL/6 and A/J mouse strains to Streptococcus suis serotype 2 infection," Infection and Immunity, vol. 76, no. 9, pp. 3901-3910, 2008.

[43] P. Y. M. Hussein, F. Zahran, A. Ashour Wahba et al., "Interleukin 10 receptor alpha subunit (IL-10RA) gene polymorphism and IL-10 serum levels in Egyptian atopic patients," Journal of Investigational Allergology \& Clinical Immunology, vol. 20, no. 1, pp. 20-26, 2010.

[44] Y. M. Hussein, S. M. Shalaby, R. H. Mohamed, and T. H. Hassan, "Association between genes encoding components of the IL-10/IL-0 receptor pathway and asthma in children," Annals of Allergy, Asthma \& Immunology, vol. 106, no. 6, pp. 474480, 2011.

[45] L. Brockmann, N. Gagliani, B. Steglich et al., "IL-10 receptor signaling is essential for TR1 cell function in vivo," The Journal of Immunology, vol. 198, no. 3, pp. 1130-1141, 2017. 
[46] P. Jeannin, S. Lecoanet, Y. Delneste, J. F. Gauchat, and J. Y. Bonnefoy, "IgE versus IgG4 production can be differentially regulated by IL-10," Journal of Immunology, vol. 160, pp. 3555-3561, 1998.

[47] F. Chung, "Anti-inflammatory cytokines in asthma and allergy: interleukin-10, interleukin-12, interferon- $\gamma$," Mediators of Inflammation, vol. 10, no. 2, pp. 51-59, 2001.

[48] L. Sun, T. T. Cornell, A. LeVine et al., "Dual role of interleukin10 in the regulation of respiratory syncitial virus (RSV)induced lung inflammation," Clinical and Experimental Immunology, vol. 172, no. 2, pp. 263-279, 2013. 